\title{
Reproductive response of Pelibuey sheep to the application of recombinant bovine somatotropin and a metabolic restorative preparation
}

\author{
Silvia Fraire-Cordero(1), Paulino Pérez Rodríguez ${ }^{(2)}$, Ponciano Pérez-Hernández ${ }^{(3)}$, \\ César Cortez-Romero ${ }^{(4)}$ and Jaime Gallegos-Sánchez ${ }^{(2)}$
}

\begin{abstract}
(1)Conacyt-Colegio de Postgraduados, Campus Campeche, Carretera Federal Haltunchén-Edzná, Km 17.5, Sihochac, C.P. 24450 Campeche, Mexico. E-mail: frairec@colpos.mx (2)Colegio de Postgraduados, Campus Montecillo, Carretera Federal MexicoTexcoco, Km 36.5, Montecillo, C.P. 56230 Estado de Mexico, Mexico. E-mail: perpdgo@colpos.mx, gallegos@colpos.mx ${ }^{(3)}$ Colegio de Postgraduados, Campus Veracruz, Carretera Federal Xalapa-Veracruz, Km 88.5, C.P. 91700 Veracruz, Mexico. E-mail: pperez@colpos.mx ${ }^{(4)}$ Colegio de Postgraduados, Campus San Luis Potosí, Agustín de Iturbide no 73, Salinas de Hidalgo, C.P. 78600 San Luis Potosí, Mexico. E-mail: ccortez@colpos.mx
\end{abstract}

Abstract - The objective of this work was to evaluate the effect of recombinant bovine somatotropin (rBST) and of the metabolic restorative preparation Metabolase (MR) on the reestablishment of the post-partum ovarian activity of Pelibuey sheep. Ninety-four ewes, with their respective lambs, were randomly assigned to one of the following treatments: T1, continuous suckling (CS); T2, CS + MR; T3, CS + rBST; and T4, CS $+\mathrm{MR}+$ rBST. Ovulating percentages, weight changes in ewes and lambs, incidence of estrus, onset and return to estrus, calving, fecundity, and prolificacy were evaluated. The highest ovulation percentages were recorded for $\mathrm{CS}$ in $\mathrm{T} 1$ and $\mathrm{T} 2$, and the lowest ones for $\mathrm{rBST}$ in $\mathrm{T} 3$ and T4. The treatments had a significant effect on lamb weight. Ewes in T3 had the lowest incidence of estrus (52.9\%), besides a greater onset $(26.8 \pm 1.9$ hours) and return to estrus (66.6\%). Calving (86.2\%) and fecundity $(1.8 \pm 0.2)$ were significantly higher in T2. The application of rBST in ewes increases lamb body weight, due to increased milk production, but affects negatively post-partum reproductive activity due to the loss of ewe body weight.

Index terms: Ovis aries, anestrus, body weight, estrus induction, growth hormone, post-partum reproductive activity.

\section{Resposta reprodutiva de ovelhas Pelibuey à aplicação de somatotropina bovina recombinante e de um reconstituinte metabólico}

Resumo - O objetivo deste trabalho foi avaliar o efeito da somatotropina bovina recombinante (rBST) e do reconstituinte metabólico Metabolase (MR) no reestabelecimento da atividade ovariana pós-parto de ovelhas Pelibuey. Noventa e quatro ovelhas, com seus respectivos cordeiros, foram distribuídas ao acaso a um dos seguintes tratamentos: T1, amamentação continua (AC); T2, AC + MR; T3, AC + rBST; e T4, AC + MR + rBST. Foram avaliados percentagem de ovulação, alterações de peso em ovelhas e carneiros, incidência do estro, início e retorno ao estro, parição, fecundidade e prolificidade. As maiores percentagens de ovulação foram registradas para AC em T1 e T2, e as menores para rBST em T3 e T4. Os tratamentos tiveram efeito significativo sobre peso dos cordeiros. As ovelhas em T3 apresentaram menor incidência de estro (52,9\%), além de maior início $(26,8 \pm 1,9$ horas) e retorno ao estro $(66,6 \%)$. A parição $(86,2 \%)$ e a fecundidade $(1,8 \pm 0,2)$ foram significativamente maiores em T2. A aplicação da rBST nas ovelhas incrementa o peso corporal dos cordeiros, em razão do aumento na produção de leite, mas afeta negativamente a atividade reprodutiva pósparto, em razão da perda de peso corporal das ovelhas.

Termos para indexação: Ovis aries, anestro, peso corporal, indução de estro, hormônio de crescimento, atividade reprodutiva pós-parto.

\section{Introduction}

The reproductive potential of ewes (Ovis aries L.) is closely related to the early resumption of cyclic ovarian activity after lambing (Fernandes et al., 2013). For this reason, it is necessary to manage the most important factors that inhibit post-partum ovarian activity, namely breastfeeding and nutrition (Orihuela et al., 2016).

The high demand for nutrients to synthesize milk, in the beginning of the post-partum period, and the limited capacity of females for food consumption
Pesq. agropec. bras., Brasília, v.53, n.12, p.1392-1398, Dec. 2018 DOI: 10.1590/S0100-204X2018001200012
This is an open-access article distributed under the Creative Commons Attribution 4.0 International License 
result in a metabolic disorder that negatively affects the production and secretion of the gonadotropinreleasing hormone $(\mathrm{GnRH})$, which delays the onset of post-partum ovarian activity (Ungerfeld \& Sanchez-Davila, 2012). The addition of gonadotropinstimulating metabolites has been shown to increase ovarian activity in ewes (Hernández-Marín et al., 2016). In cows, recombinant bovine somatotropin (rBST) administration increases serum concentrations of insulin-like growth factor-1 (IGF-I) and of insulin, as well as the production of estradiol in the follicles, improving embryo development (Hernández-Cerón \& Gutierrez-Aguilar, 2013). In ewes, the administration of rBST increases milk production (Sallam et al., 2005), fecundity, and prolificacy (Sosa-Pérez et al., 2014). Based on these studies, the application of rBST could increase the body weight of lambs without affecting the body weight of adult females and, when administered together with a metabolic restorative preparation, such as Metabolase, could also improve the reproductive variables in hair sheep ewes treated for estrus induction.

The objective of this work was to evaluate the effect of recombinant bovine somatotropin and of the metabolic restorative preparation Metabolase on the reestablishment of the post-partum ovarian activity of Pelibuey sheep.

\section{Materials and Methods}

The study was carried out from December 2011 to June 2012, in the laboratory of sheep and goat reproduction at the Montecillo campus of Colegio de Postgraduados, in the State of Mexico, Mexico $\left(19^{\circ} 29^{\prime} \mathrm{N}, 98^{\circ} 53^{\prime} \mathrm{W}\right.$, at $2,250-\mathrm{m}$ altitude). The climate of the region is sub-humid temperate, with summer rains (García, 2004).

Ninety-four adult ewes, with their respective lambs, and six sexually active four-year-old adult rams were used for the experiment; the average weight of ewes was $57.4 \pm 0.9 \mathrm{~kg}$. Ewes and lambs were randomly assigned to one of the following treatments, eight days after lambing: T1, continuous suckling (CS; n=29); T2, $\mathrm{CS}+$ the metabolic restorative preparation Metabolase (Schütze-Segen, Mexico City, Mexico) (MR; n=29); T3, CS + rBST (Boostin-S, MSD Salud Animal, Mexico City, Mexico) ( $\mathrm{n}=17)$; and T4, CS + MR + rBST $(n=19)$.
At 50 days of gestation, $1 \mathrm{~mL} \mathrm{Mu-Se} \mathrm{selenium}$ (MSD Salud Animal, Mexico City, Mexico) per $50 \mathrm{~kg}$ body weight was applied subcutaneously to all ewes. At 90 days of gestation, $2 \mathrm{~mL}$ Toxo-Bac pneumonia vaccine (Inifap, Mexico City, Mexico) were applied subcutaneously. At birth, 5\% metallic iodine with alcohol were used to disinfect the navel of each lamb, and $0.2 \mathrm{~mL} \mathrm{Mu}-\mathrm{Se}$ was applied subcutaneously. Ewes and lambs were weighed at birth and, then, every 9 days until 63 days of age. Lambs were weaned when they were 60 days old.

Ewes were fed twice daily, in the same trough, each time with $1.5 \mathrm{~kg}$ balanced feed $-70 \%$ oat hay and $30 \%$ of the commercial concentrate Borrega Plus, with 150 g crude protein and 2.9 Mcal metabolizable energy per $\mathrm{kg}$ dry matter per ewe. Each ram was fed $3.0 \mathrm{~kg}$ of this same diet, also twice a day. Water and mineral salts were offered ad libitum to all animals. Lambs were fed milk from their respective mothers, and from day 11 of age they were offered the Iniciador Dulce-20 starter concentrate, with $20 \%$ crude protein, ad libitum, in feeders excluding ewes, until weaning.

Blood samples $(5 \mathrm{~mL})$ were taken from all ewes on days 24 and 29 post-partum (DPP), using jugular vein puncture, and were injected in BD Vacutainer blood collection tubes (Becton, Dickinson and Company, Franklin Lakes, NJ, USA), without anticoagulant. Samples were centrifuged at $693 \mathrm{~g}(2,500 \mathrm{rpm})$, for $15 \mathrm{~min}$, in the C-600 centrifuge (Solbat C.A. de C.V. Aparatos Científicos, Puebla City, Puebla State, Mexico). Subsequently, serum was collected by decantation and stored at $-20^{\circ} \mathrm{C}$ until analysis. The concentration of progesterone $\left(\mathrm{P}_{4}\right)$ was determined using the Coat-a-Count solid phase radioimmunoassay (Siemens Medical Solutions Diagnostics, Los Angeles, CA, USA), with an analysis sensitivity of $0.02 \mathrm{ng} \mathrm{mL}^{-1}$ and an intra-assay coefficient of variation of $8.8 \%$. A ewe was considered to have restored ovarian activity when the $\mathrm{P}_{4}$ was greater than $0.5 \mathrm{ng} \mathrm{mL}^{-1}$ in two consecutive samples or more than $1.0 \mathrm{ng} \mathrm{mL}^{-1}$ in a single sample (Thorburn et al., 1969).

At 18 DPP, the ewes in $\mathrm{T} 3$ and $\mathrm{T} 4$ received a 250-mg dose of rBST, administered subcutaneously to increase milk production for lambs. Subsequently, ewes were induced to estrus, at 33 DPP, with the CIDR intravaginal device (Zoetis Inc., Parsippany-Troy Hills, NJ, USA), with $0.3 \mathrm{~g} \mathrm{P}_{4}$, during five days. On the third day of the protocol, $1.0 \mathrm{~mL}$ Celosil (MSD

Pesq. agropec. bras., Brasília, v.53, n.12, p.1392-1398, Dec. 2018 DOI: $10.1590 / \mathrm{S} 0100-204 \mathrm{X} 2018001200012$ 
Salud Animal, Ciudad de México, Mexico), a PGF2 $\alpha$ analog, was administered intramuscularly to all ewes. In addition, a dose of $200 \mathrm{~mL}$ Metabolase $-100 \mathrm{~mL}$ intravenously and $100 \mathrm{~mL}$ subcutaneously - was given per ewe in T2 and T4. Each $100 \mathrm{~mL}$ Metabolase contained $613.3 \mathrm{mg}$ L-carnitine, $20 \mathrm{mg}$ thioctic acid (lipoic acid), $15 \mathrm{mg}$ pyridoxine hydrochloride, $3.0 \mathrm{mg}$ cyanocobalamin, $2,000 \mathrm{mg}$ d-1-acetylmethionine, 240 $\mathrm{mg}$ L-arginine, $153.2 \mathrm{mg}$ L-ornithine hydrochloride, $120 \mathrm{mg}$ L-citrulline, $62.5 \mathrm{mg}$ L-lysine hydrochloride, $150 \mathrm{mg}$ glycine, $150 \mathrm{mg}$ aspartic acid, $150 \mathrm{mg}$ glutamic acid, 5,000 mg fructose, and 8,000 $\mathrm{mg}$ sorbitol. On the fifth day of the protocol, $\mathrm{P}_{4}$ devices were removed, and the detection of estrus - when the ewe remained motionless and allowed the ram to mount - was performed every 4 hours. A ewe was considered to have responded positively to the treatment if it entered estrus during the first 70 hours after being exposed to six four-year-old rams, each covered with an apron to prevent intercourse. Intrauterine insemination was performed 12 hours after estrus detection, by injecting $0.25 \mathrm{~mL}$ diluted and refrigerated semen, with an average concentration of $230 \times 10^{6}$ spermatozoa per millimeter. Forty days after artificial insemination (AI), gestation diagnoses were performed with the USM CTS-900 portable ultrasound (Shantou Institute of Ultrasonic Instruments Co., Ltd., Guangdong, China), fitted to a 3.5-7-Mhz abdominal transducer.

The response variables studied were the percentage of ewes ovulating before 29 DPP and the changes in the body weights of ewes and lambs. Induction was evaluated using incidence of estrus, onset and return of estrus, calving, fecundity, and prolificacy. To determine the number of ewes that resumed ovarian activity before $29 \mathrm{DPP}$, the number of ovulating ewes, detected by the quantity of $\mathrm{P}_{4}$ in serum, was counted. Weight change in ewes and lambs was assessed from weight data obtained every 9 days, until 63 DPP. To calculate the incidence of estrus, the number of ewes with external estrus manifestations was divided by the total number of ewes in the treatment. Onset of estrus was considered as the time necessary to reach estrus, after removal of the $\mathrm{P}_{4}$ device, whereas return to estrus was the number of ewes displaying estrus within 20 days after AI. Calving was calculated as the number of ewes that gave birth out of all ewes in a treatment, after the first insemination. For fecundity determination, the number of lambs born was divided by the number of ewes in a treatment, and, for prolificacy, the number of lambs born from each ewe was counted.

Analyses of the percentage of ovulating ewes, incidence of estrus, return to estrus, and calving were performed using a logistic regression model. Body weight changes in ewes and lambs were analyzed using repeated measurements, in a mixed model (Littell et al., 1998), with means compared by Tukey's test. The time necessary for the beginning of estrus was analyzed using the life-time method, and differences between treatments were established by the logrank test (Kalbfleisch \& Prentice, 2002). Poisson and negative binomial regressions (Lawless, 1987) were used to analyze fecundity and prolificacy. The treatment effects were assessed with the generalized likelihood ratio test, at 5\% probability. All analyzes were performed using the SAS software (SAS Institute, Inc., Cary, NC, USA).

\section{Results and Discussion}

The percentage of ewes ovulating at 29 DPP was greater in the $\mathrm{T} 1$ and $\mathrm{T} 2$ treatments. In $\mathrm{T} 3$, in which ewes only received $\mathrm{rBST}$, the lowest percentage of ovulation was observed (Table 1), showing that the application of this product, at 18 DPP, negatively affected ovulation, preventing it; this was attributed to weight loss and low body weights at lambing (Figure 1). According to Karakuş \& Atmaca (2016), weight loss and body condition during lactation inhibit the reestablishment of ovarian activity after lambing. The results obtained in the present study are

Table 1. Percentage of ovulation 29 days post-partum in Pelibuey hair sheep (Ovis aries) ewes receiving recombinant bovine somatotropin (rBST) and a metabolic restorative preparation $(\mathrm{MR})^{(1)}$.

\begin{tabular}{lccc}
\hline Treatment $^{(2)}$ & Number & $\begin{array}{c}\text { Ovulating } \\
\text { animals }\end{array}$ & $\begin{array}{c}\text { Ovulation } \\
(\%)\end{array}$ \\
\hline T1, continuous suckling (CS) & 29 & 13 & $44.8 \mathrm{a}$ \\
T2, CS + MR & 29 & 14 & $48.3 \mathrm{a}$ \\
T3, CS + rBST & 17 & 02 & $11.7 \mathrm{~b}$ \\
T4, CS + MR + rBST & 19 & 15 & $78.9 \mathrm{c}$ \\
\hline
\end{tabular}

(1)Means followed by equal letters do not differ by Tukey's test, at $5 \%$ probability. ${ }^{(2)} \mathrm{T} 2$, application at 36 days post-partum (DPP); T3, application at 18 and 36 DPP; and T4, application of MR at 36 DPP and of rBST at 18 and 36 DPP. 
similar to those of Méndez Roblero (2014), who found that $12.5 \%$ of ewes ovulated before 30 DPP, under similar ovulation induction protocols and with rBST application. The greatest percentage of ovulation in T4 ewes is likely to be associated with their better calving weight (Figure 1), indicating that ewes with high body condition and greater birth weights tend to lose less weight in response to the application of rBST.

Treatments did not differ regarding weight changes in ewes; however, there were differences between application period (DPP), with a significant interaction between period and treatments. The weight of ewes was maintained or increased over the first nine days post-partum, but decreased afterwards. Ewes in $\mathrm{T} 1$ and $\mathrm{T} 2$ maintained the most stable weights over time, while those in T3 and T4 had a large drop in body weight after rBST applications (Figure 1). This hormone promotes hepatic gluconeogenesis and reduces insulin activity to inhibit insulin; therefore, additional glucose is used by the mammary gland as a precursor for lactose, which explains the increase in production (Prado et al., 2003; Lucy, 2008), resulting in lamb weight gain (Figure 2). In the beginning of the study, ewes in T3 also had a lower birth weight than in the other treatments. The greatest weight losses were observed during periods from 18 to 27 DPP and from 36 to 45 DPP for all ewes, as also verified by Méndez Roblero (2014). The increase in nutritional requirements imposed by milk production and the application of rBST induced females to use their own reserves, causing weight and body condition losses; however, due to the use of the metabolic restorative preparation, these results were less severe than those for T4 ewes.

The change in lamb body weight increased over time and differed between treatments and periods, with a significant period $\mathrm{x}$ treatment interaction. Lambs from mothers that received rBST showed the best weights at weaning due to the higher milk production of their mothers (Figure 2). It should be noted that lamb weights among the other treatments were greater than those found by Pérez Hernández et al. (2009) for hair lambs. Therefore, the application of rBST to ewes improves lamb weight at weaning as milk production increases, resulting in a greater ewe body weight loss (Figure 1).

Estrus was reduced in $\mathrm{T} 3$ ewes with the application of rBST (Table 2), which was related to the greater weight loss (Figure 1) due to energy prioritization for

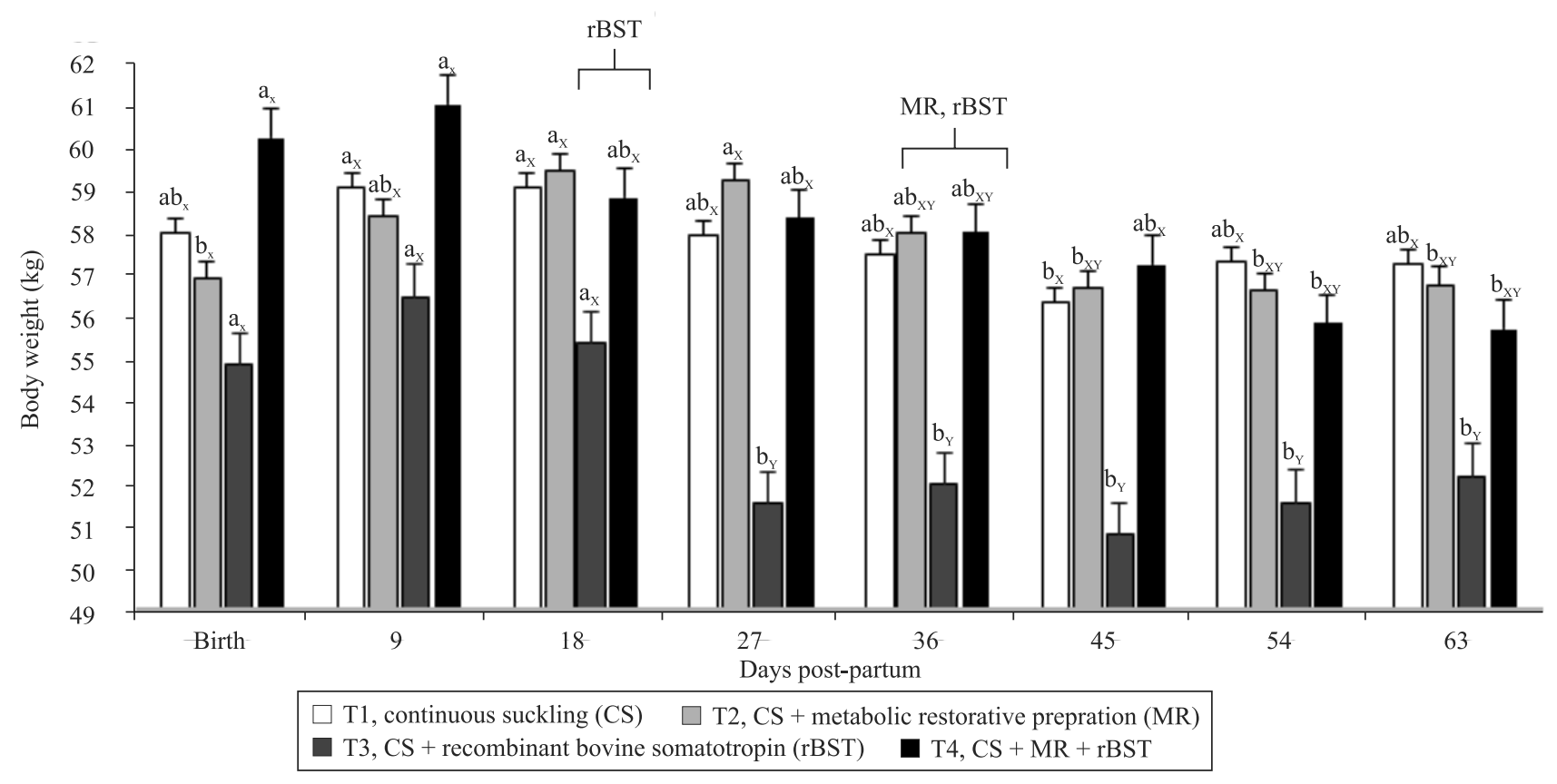

Figure 1. Body weight changes during post-partum period, in Pelibuey hair sheep (Ovis aries) ewes receiving recombinant bovine somatotropin (rBST) and a metabolic restorative preparation (MR). Bars with equal letters, a and b between periods and $\mathrm{Y}$ and $\mathrm{X}$ between treatments, do not differ by Tukey's test, at 5\% probability. 
weight maintenance, milk production for lambs, and reproduction (Orihuela et al., 2016). Therefore, under these conditions, progesterone administration did not induce females to present estrus, differently from cyclic ewes, which showed $98.3 \%$ of estrus after receiving $250 \mathrm{mg}$ rBST during a nine-day protocol (Sosa-Pérez et al., 2014). Together, these results show that lambing weight post-partum affects the responses to an estrus induction protocol, emphasizing the importance of adequately feeding ewes to obtain better reproductive and productive efficiencies.
The onset of estrus was greater in T3 ewes (Table 2) - although half of them did not show estrus -, indicating the importance of body weight. In ewes with a greater weight at calving, the application of rBST stimulates steroidogenesis and follicular development, increasing estradiol production, which is necessary for earlier external manifestations of estrus. The lack of external manifestations was due to greater weight loss, which reduced the concentrations of leptin and insulin, inhibiting the pulsatile secretion of the GnRH needed to achieve a preovulatory luteinizing hormone

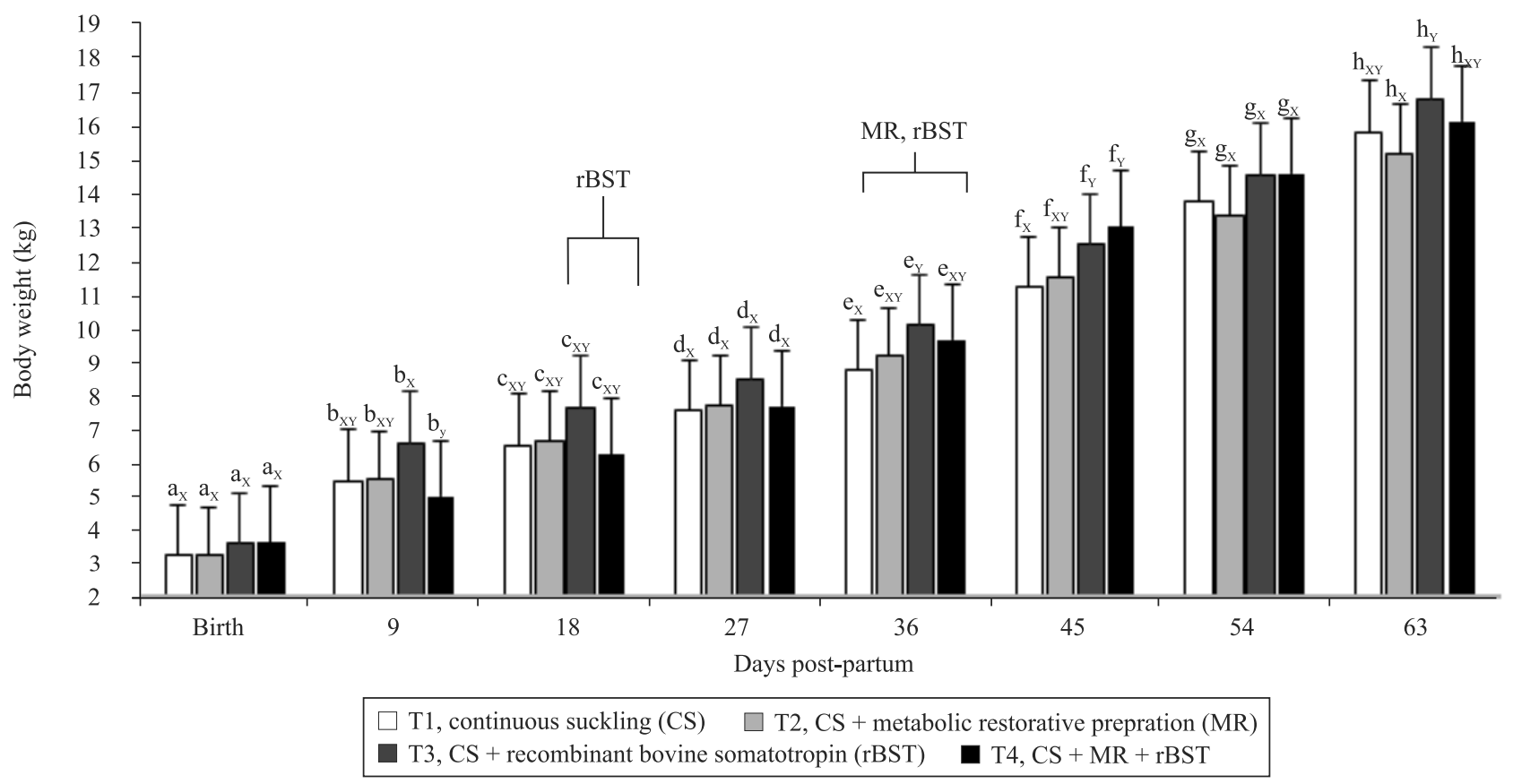

Figure 2. Changes in body weight of Pelibuey hair lambs (Ovis aries), during the first 63 days of age, from ewes receiving recombinant bovine somatotropin (rBST) and a metabolic restorative preparation (MR). Bars with equal letters, a and $b$ between periods and $\mathrm{Y}$ and $\mathrm{X}$ between treatments, do not differ by Tukey's test, at $5 \%$ probability.

Table 2. Reproductive variables in Pelibuey hair sheep (Ovis aries) ewes receiving recombinant bovine somatotropin (rBST) and a metabolic restorative preparation ${ }^{(1)}$.

\begin{tabular}{|c|c|c|c|c|c|}
\hline Treatment $^{(2)}$ & Number & $\begin{array}{c}\text { Inseminated } \\
\text { animals }\end{array}$ & $\begin{array}{c}\text { Incidence of } \\
\text { estrus (\%) }\end{array}$ & $\begin{array}{c}\text { Initiation of } \\
\text { estrus (hours) }\end{array}$ & $\begin{array}{l}\text { Return to } \\
\text { estrus (\%) }\end{array}$ \\
\hline $\mathrm{T} 1$, continuous suckling $(\mathrm{CS})$ & 29 & 29 & $100.0 \mathrm{a}$ & $25.9 \pm 1.9 \mathrm{a}$ & $27.5 \mathrm{a}$ \\
\hline $\mathrm{T} 2, \mathrm{CS}+$ metabolic restorative preparation (MR) & 29 & 29 & $100.0 \mathrm{a}$ & $25.7 \pm 0.7 \mathrm{a}$ & $13.7 \mathrm{a}$ \\
\hline $\mathrm{T} 3, \mathrm{CS}+$ recombinant bovine somatotropin (rBST) & 17 & 09 & $52.9 \mathrm{~b}$ & $26.8 \pm 1.9 \mathrm{~b}$ & $66.6 b$ \\
\hline $\mathrm{T} 4, \mathrm{CS}+\mathrm{MR}+\mathrm{rBST}$ & 19 & 19 & $100.0 \mathrm{a}$ & $27.4 \pm 2.2 \mathrm{a}$ & $21.0 \mathrm{a}$ \\
\hline
\end{tabular}

(1) Means followed by equal letters do not differ by Tukey's test, at $5 \%$ probability. ${ }^{(2)}$ T2, application at 36 days post-partum (DPP); T3, application at 18 and 36 DPP; and T4, application of MR at 36 DPP and of rBST at 18 and 36 DPP. 
peak (Guzmán-Sánchez et al., 2012), in order to trigger reproductive events. Conversely, ewes receiving the metabolic restorative preparation, Metabolase, in T2, entered estrus earlier, and the manifestation of this state was more uniform among them (Table 2), most likely due to their better follicular development and stimulation of the hypothalamic-pituitary axis. Ewes in T3 had greater return to estrus compared with those of the other treatments (Table 2). This was possibly attributed to the lower percentage of ovulating females, lower incidence of estrus, and greater weight loss. Yilmaz et al. (2011) observed that the percentage of ewes returning to estrus increased according to body weight and condition, so that ewes must, at least, have an average body condition of 3.5 to 4.0 , on a scale of $1.0-5.0$, at the time of coverage.

The highest calving percentage was observed for ewes in T2; however, similar results were obtained in T4 (Table 3). This indicates that the application of the metabolic restorative preparation to ewes improved calving percentage. Lucy (2008) concluded that the nutritional needs of ewes in production are increased when rBST is applied; however, when provided, nutrients can favor the production, fertilization, and implantation of ovules. In the present study, the fecundity of $\mathrm{T} 2$ ewes also differed significantly from that of those in $\mathrm{T} 1$ and $\mathrm{T} 3$, but was similar to that of those in T4; the lowest value was observed for T3 ewes (Table 3). Likewise, fecundity was increased by the administration of the metabolic restorative preparation

Table 3. Reproductive variables in Pelibuey hair sheep (Ovis aries) ewes in continuos suckling (CS) receiving recombinant bovine somatotropin ( $\mathrm{rBST}$ ) and a metabolic restorative preparation $(\mathrm{MR})^{(1)}$.

\begin{tabular}{lccccc}
\hline Treatment $^{(2)}$ & $\begin{array}{c}\text { Num- } \\
\text { ber }\end{array}$ & $\begin{array}{c}\text { Insemi- } \\
\text { nated } \\
\text { animals }\end{array}$ & $\begin{array}{c}\text { Calving } \\
(\%)\end{array}$ & Fecundity & Prolificity \\
\hline T1, CS & 29 & 29 & $55.2 \mathrm{ac}$ & $1.0 \pm 0.2 \mathrm{a}$ & $1.9 \pm 0.2 \mathrm{a}$ \\
$\mathrm{T} 2, \mathrm{CS}+\mathrm{MR}$ & 29 & 29 & $86.2 \mathrm{~b}$ & $1.8 \pm 0.2 \mathrm{~b}$ & $2.0 \pm 0.2 \mathrm{a}$ \\
$\mathrm{T} 3, \mathrm{CS}+\mathrm{rBST}$ & 17 & 09 & $22.2 \mathrm{a}$ & $0.23 \pm 0.2 \mathrm{c}$ & $2.0 \pm 0.4 \mathrm{a}$ \\
$\mathrm{T} 4, \mathrm{CS}+\mathrm{MR}$ & 19 & 19 & $63.2 \mathrm{~b}$ & $1.37 \pm 0.2 \mathrm{ab}$ & $1.8 \pm 0.2 \mathrm{a}$ \\
$\quad+\mathrm{rBST}$ & & & & & \\
\hline
\end{tabular}

(1)Means followed by equal letters do not differ by Tukey's test, at $5 \%$ probability. ${ }^{(2)} \mathrm{T} 2$, application at 36 days post-partum (DPP); T3, application at 18 and 36 DPP; and T4, application of MR at 36 DPP and of rBST at 18 and 36 DPP. since more ewes ovulated at 29 DPP (Table 1) and more were calving (Table 3). In the case of T3 ewes, fecundity was lower because fewer presented estrus and became pregnant; weight loss also contributed and had repercussions on all reproductive variables. The results of the present study are similar to those of Méndez Roblero (2014). According to Rivas López et al. (2011), when improved, fertility and prolificacy result in greater embryonic survival. This was probably the case in T2 and T4 ewes. Prolificacy did not differ between treatments (Table 3), and the obtained values were lower than those reported by Sosa-Pérez et al. (2014), when evaluating cyclic Pelibuey ewes treated with equine chorionic gonadotropin and rBST (2.02 \pm 0.87 lambs per ewe).

\section{Conclusions}

1. The restart of cyclic post-partum activity and reproductive variables are negatively affected by the administration of recombinant bovine somatotropin.

2. The combination of recombinant bovine somatotropin with a metabolic restorative preparation can be used to improve calving percentage and fecundity, under an ovulation induction protocol of five days post-partum.

3. The application of recombinant bovine somatotropin at 18 and 36 days post-partum positively influences lamb body weight.

\section{References}

FERNANDES, C.E.; CIGERZA, C.F.; PINTO, G. dos S.; MIAZI, C.; BARBOSA-FERREIRA, M.; MARTINS, C.F. Características do parto e involução uterina em ovelhas nativas do Pantanal brasileiro. Ciência Animal Brasileira, v.14, p.245-252, 2013. DOI: 10.5216/cab.v14i2.17926.

GARCÍA, E. Modificaciones al sistema de clasificación climática de Köppen. 5.ed. Ciudad de México: Universidad Nacional Autónoma de México, Instituto de Geografía, 2004. 90p.

GUZMÁN-SÁNCHEZ, A.; ROSALES-TORRES, A.M.; GUTIÉRREZ AGUILAR, C.G. Neuroendocrine effects of Insulin, IGF-I and leptin on the secretion of the gonadotropin-releasing hormone (GnRH). Tropical and Subtropical Agroecosystems, v.15, p.S79-S90, 2012. Suppl.

HERNÁNDEZ-CERÓN, J.; GUTIERREZ-AGUILAR, C.G. La somatotropina bovina recombinante y la reproducción en bovinos, ovinos y caprinos. Agrociencia, v.47, p.35-45, 2013.

HERNÁNDEZ-MARÍN, J.A.; PRO-MARTÍNEZ, A.; CORTEZROMERO, C.; PÉREZ-HERNÁNDEZ, P.; HERRERA-

Pesq. agropec. bras., Brasília, v.53, n.12, p.1392-1398, Dec. 2018 DOI: $10.1590 / \mathrm{S} 0100-204 \mathrm{X} 2018001200012$ 
CORREDOR, C.A.; GALLEGOS-SÁNCHEZ, J. Inducción de la ovulación con efecto macho y un reconstituyente energético en ovejas Pelibuey prepúberes. Agrociencia, v.50, p.811-823, 2016.

KALBFLEISCH, J.D.; PRENTICE, R.L. The statistical analysis of failure time data. 2nd ed. New Jersey: Wiley-Interscience, 2002. 462p. DOI: 10.1002/9781118032985.

KARAKUŞ, F.; ATMACA, M. The effect of ewe body condition at lambing on growth of lambs and colostral specific gravity. Archives Animal Breeding, v.59, p.107-112, 2016. DOI: 10.5194/ aab-59-107-2016.

LAWLESS, J.F. Negative binomial and mixed Poisson regression. The Canadian Journal of Statistics, v.15, p.209-225, 1987. DOI: $10.2307 / 3314912$.

LITTELL, R.C.; HENRY, P.R.; AMMERMAN, C.B. Statistical analysis of repeated measures data using SAS procedures. Journal of Animal Science, v.76, p.1216-1231, 1998. DOI: $10.2527 / 1998.7641216 x$.

LUCY, M.C. Functional differences in the growth hormone and insulin-like growth factor axis in cattle and pigs: implications for post-partum nutrition and reproduction. Reproduction in Domestic Animals, v.43, p.31-39, 2008. DOI: 10.1111/j.14390531.2008.01140.x.

MÉNDEZ ROBLERO, H.Z. Somatotropina bovina recombinante (rbST) y su efecto en la inducción de la ovulación en ovejas Pelibuey amamantando. 2014. 60p. Tesis (Maestra) Colegio de Postgraduados, Montecillo.

ORIHUELA, A.; VALDEZ, D.; UNGERFELD, R. The effect of permanent or temporary contact with the lamb and contact with males on the lambing to first ovulation interval in Saint Croix sheep. Applied Animal Behaviour Science, v.181, p.100-104, 2016. DOI: 10.1016/j.applanim.2016.05.009.

PÉREZ HERNÁNDEZ, P.; HERNÁNDEZ VALDEZ, V.M.; SANDOVAL, B.F.; TORRES HERNANDEZ, G.; DÍAZ RIVERA, P.; SÁNCHEZ, J.G. Efecto del tipo de amamantamiento en la actividad ovárica postparto de ovejas Pelibuey y tasas de crecimiento de corderos en los primeros 90 días de edad. Revista Científica. Facultad de Ciencias Veterinarias, v.19, p.343-349, 2009.
PRADO, I.N. do; NASCIMENTO, W.G. do; NEGRÃO, J.A.; RIGOLON, L.P.; SCHILLER, S. de S.; SAKUNO, M.L.D.; PESSINI, G.L. Somatotropina bovina recombinante (rBST) nos aspectos hematológicos e metabólitos do sangue de novilhas ( $1 / 2$ Nelore x $1 / 2$ Red Angus) em confinamento. Revista Brasileira de Zootecnia, v.32, p.465-472, 2003. DOI: 10.1590/S151635982003000200027 .

RIVAS LÓPEZ, P.C.; SUAREZ LONDOÑO, A.; RAMÍREZ CARDONA, E. Influencia de las hormonas metabólicas y la nutrición en el desarrollo folicular en el ganado bovino: implicaciones prácticas. Revista de Medicina Veterinaria, n.21, p.155-173, 2011. DOI: 10.19052/mv.574.

SALLAM, S.M.A.; NASSER, M.E.A.; YOUSEF, M.I. Effect of recombinant bovine somatotropin on sheep milk production, composition and some hemato-biochemical components. Small Ruminant Research, v.56, p.165-171, 2005. DOI: 10.1016/j. smallrumres.2004.06.010.

SOSA-PÉREZ, G.; PÉREZ-HERNÁNDEZ，P.; VAQUERAHUERTA, H.; SALAZAR-ORTIZ, J.; SÁNCHEZ-DEL-REAL, C.; CADENA-VILLEGAS, S.; GALLEGOS-SÁNCHEZ, J. Somatotropina bovina recombinante en sincronización de estros y prolificidad de ovejas Pelibuey. Archivos de Zootecnia, v.63, p.219-222, 2014. DOI: 10.4321/s0004-05922014000100025.

THORBURN, G.D.; BASSETT, J.M.; SMITH, I.D. Progesterone concentrations in the peripheral plasma of sheep during the oestrous cycle. Journal of Endocrinology, v.45, p.459-469, 1969. DOI: $10.1677 /$ joe.0.0450459.

UNGERFELD, R.; SANCHEZ-DAVILA, F. Oestrus synchronization in postpartum autumn-lambing ewes: effect of postpartum time, parity, and early weaning. Spanish Journal of Agricultural Research, v.10, p.62-68, 2012. DOI: 10.5424/ sjar/2012101-233-11.

YILMAZ, M.; ALTIN, T.; KARACA, O.; CEMAL, I.; BARDAKCIOGLU, H.E.; YILMAZ, O.; TASKIN, T. Effect of body condition score at mating on the reproductive performance of Kivircik sheep under an extensive production system. Tropical Animal Health and Production, v.43, p.1555-1560, 2011. DOI: 10.1007/s11250-011-9841-1.

Received on October 12, 2017 and accepted on February 18, 2018

Pesq. agropec. bras., Brasília, v.53, n.12, p.1392-1398, Dec. 2018

DOI: 10.1590/S0100-204X2018001200012 